\title{
Employing Diversity and Similarity Indices to Evaluate Geopedological Soil Mapping in Miyaneh, East Azerbaijan Province, Iran
}

\author{
Naser Nazari, Shahla Mahmoodi*, Mohammad Hassan Masihabadi \\ Department of Soil Science, College of Agriculture and Natural Resources, Science and Research Branch, Islamic Azad University, \\ Tehran, Iran \\ Email:nas.nazari@gmail.com,nazari@m-iau.ac.ir,*smahmodi@ut.ac.ir,hmasih@yahoo.com
}

How to cite this paper: Nazari, N., Mahmoodi, S. and Masihabadi, M.H. (2016) Employing Diversity and Similarity Indices to Evaluate Geopedological Soil Mapping in Miyaneh, East Azerbaijan Province, Iran. Open Journal of Geology, 6, 1221-1239. http://dx.doi.org/10.4236/ojg.2016.610090

Received: August 8, 2016

Accepted: September 27, 2016

Published: September 30, 2016

Copyright $\odot 2016$ by authors and Scientific Research Publishing Inc. This work is licensed under the Creative Commons Attribution International License (CC BY 4.0).

http://creativecommons.org/licenses/by/4.0/ (c) (i) Open Access

\begin{abstract}
The geopedological viewpoint attempts to distinguish and introduce the smallest map unit that has the highest levels of homogeneity and uniformity with respect to landform, lithology, and soil, especially if the relationship between geomorphology and soils in the region is well defined. This research intended to investigate the degree of validity generalization of results obtained in the geopedology approach for similar landforms in the Miayneh region of East Azerbaijan Province, Iran. For this purpose, soil diversity study was conducted through measuring it in a hierarchical sequence in categories of USDA soil taxonomy and by comparing similar units in the geopedological method through employing pedodiversity and similarity indices. After preparing the initial interpretative map (based on aerial photographs) at a scale of 1:20,000, the HPu211 unit that covered the greatest delineation of study area was selected and 28 soil profiles, about 90 meters apart, were excavated, described, and sampled in this unit. The degree of validity generalization of geopedological results for the mentioned unit was determined by digging 14 other soil profiles in a similar unit, called the validation area, which was located outside of the sample area. Results indicated that the value of Shannon's diversity index increased from the level of soil order to soil family in both the sample and the generalization areas; however, only at the soil family level were there significant differences between soil diversity in the two areas at the confidence level of $95 \%$. As well as classification of the profiles dug in the generalization area was different from that of the profiles dug in the sample area at the category of soil family. Therefore, it is possible that management generalizability in this method, even at the detailed scale, can satisfy the related needs. Consequently, interpretative or managerial purity of geopedological units must be considered in future research.
\end{abstract}




\section{Keywords}

Field Operation, Validation Area, Similarity Index, Soil Surveys, Landform, Diversity Index

\section{Introduction}

The geopedological viewpoint is a systematic method of analyzing geomorphic surfaces that tries to soils mapping by using a comprehensive study of the relationship between soil and geomorphology and of their interactions. It also attempts to distinguish and introduce the smallest map unit that has the highest levels of homogeneity and uniformity (with respect to landform, lithology, and soil), especially if the relationship between geomorphology and soils in the region is well defined [1].

In general, the main goal in geopedology is to organize and classify soils (pedons) based on their geomorphological evidence on the ground surface and through employing a hierarchical structure [2] that usually includes landscape, relief, lithology, and landform [1]. This method is based on the degree of correctness of the following hypotheses [3]:

- Soils have greater uniformity at the lower levels of geopedological hierarchy.

- Lower levels of the geopedological hierarchy indicate the sameness of units having the same name in the region.

- The borders drawn by analysis of the landscape separate the major changes present in the soils.

- The sample area is the correct and real representative of the units under study so that the soil pattern present in the sample area can be used to extrapolate the units that were not visited (Figure 1).

The soils cape is the pedologic portion of the landscape. Soil scientists have examined it mainly within the field of soil landscape analysis, which traditionally regards a quantitative characterization of the spatial pattern and complexity of soil landscapes [4].

The quality of any work or tool is determined when it is performed or used. Therefore, if we consider soil maps tools that indicate the properties of the soil and land, then we can examine their quality when we actually confront them. In general, the quality of maps is a function of three properties: "reliability of the information", "the degree of relatedness of the information to the goals", "the way the information is presented" [5]. Of course, Western [6] has added another property that is called, "information application".

Traditional pattern or routine soil survey studies and soil mapping based on the ability and experience of experts in the interpretation of the original soil forming processes and environmental factors involved in the formation of the landscape is based. So, data and maps derived from such a model, usually followed disability soil studies in describing the structure and dynamic properties of continuous landscape reveal [7]. On the other hand, increase large soil samplings in order to enhance the accuracy of map 


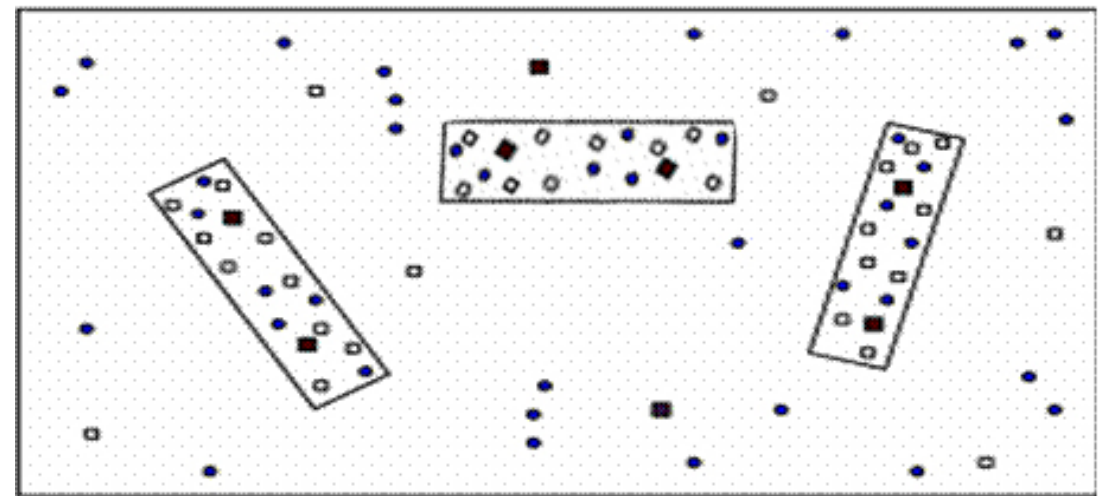

Figure 1. Distribution and type of observation points in the sample area. $\bullet=$ Augering; ${ }^{\circ}=$ observation point; $\bullet=$ profile description.

ping or zoning and estimate the characteristics of the soil, is inevitable that it also requires a lot of time and money [8]. Therefore, in order to reduce the cost and time of implementation of the Soil studies as well as increasing their accuracy, geopedology approach first by Zinck was founded in Faculty of Geo-Information Science and Earth Observation of the University of Twente (ITC) [2]. Rossiter [1] believes this method is widely used for semi-detailed studies. In this way from the five soil forming factors, there factors namely time, parent material and topography are used to separate soil units so that by checking the lithologic units parent material and age are identified.

Since methods of mapping depend on their attitudes toward similarities between soils [9], attention to questions such as similarity indices and soil diversity (and its various aspects) can be useful for qualitative and quantitative judgment concerning the degree of validity and the quality of a soil map.

The increased extinction of species under the pressure resulting from human activities in the environment has been accompanied in recent years by a great tendency of researchers to evaluate and preserve biodiversity [10]. Therefore, ecologists have employed diversity models and indices to study factors encompassing structure and organization of ecosystems at various levels of spatial differentiation. Despite the great potential of these indices, these strategies have rarely been applied in studies of abiotic structures in landscapes, although they may be used to discover, quantify, and compare the complexity of soil patterns in various environments and regions. Therefore, it is important to pay attention to the concept of soil diversity because it is mainly considered a property of an organized natural community that is created through processes of evolutionary ecology [11].

In general, soil diversity can be defined as a criterion of soil spatial variability or a function of soil forming factors [12].

In recent decades, use of biodiversity indices such as the Shannon index has attracted attention in carrying out soil diversity studies [10], [13].

Ibanez et al. [11] were the first to use ecological diversity indices as criteria in soil diversity measurements. These indices included richness, evenness, and diversity. Richness is related to the number of existing phenomena (such as soil taxa at a category of 
the USDA soil taxonomy system) in a region under study. Evenness indicates the relative frequency of each existing phenomenon (such as the relative area occupied by each soil category). Diversity is the index that involves both richness and evenness, and the larger values of the richness and evenness indices are a reason for the existence of greater diversity [10] [11]. Soil diversity can be analyzed from various viewpoints including taxonomic pedodiversity, genetic pedodiversity, functional pedodiversity, and diversity of soil properties [14] [15].

Results of research conducted by Ibanez et al. [11] showed that the degree of richness in soil layers increased with increases in the sampled area and, therefore, it could be imagined that biodiversity and pedodiversity behaved similarly. Ibanez et al. [13] showed the values of evenness and diversity indices in average geographical latitudes were greater compared to those in latitudes close to the equator and the northern latitudes. They concluded that soil patterns of various climatic regions were completely connected to each other based on a gradient dependent on geographical latitudes. Saldana and Ibanez [15] applied richness and evenness indices on a chronosequence of soils formed on fluvial terraces in northeastern Madrid (Spain) and noticed that soil richness increased from the lower (younger) terraces towards the upper (older) ones. Moreover, they stated that soil diversity was enhanced by more accurate classification and also with increases in the study area. Furthermore, their results suggested taxonomic pedodiversity increased in proportion to increases in the age of the terraces, while genetic pedodiversity decreased with increases in the age of the terraces. Toomanian et al. [14] used a geomorphic hierarchical method to study taxonomic and genetic pedodiversity of the Zayandeh-Rood Valley. Results showed that, at lower levels of the landscape towards the geomorphic surfaces, the value of Shannon's diversity index increased. Moreover, the sequence of soil horizons at the family level indicated that soil families had high values of diversity indices within geomorphic surfaces.

In any case, when the communities under study exhibit great changes, it is possible that comparison of diversity indices will not be significant. Furthermore, diversity indices usually lack the necessary changeability for places that have similar species at different proportions. In such cases, application of similarity indices can eliminate the mentioned shortcomings [16].

Similarity refers to changes that exist between various goals (entities). Changeability also indicates the degree of existing differences between values of properties (samples) when two or more properties (samples) are compared. In other words, the similarity test of the mentioned communities is a suitable method for comparing communities at different places or at different times. In fact, a similarity coefficient measures similarity between two individuals (communities) based on presence or absence of variables and/or their qualitative or quantitative properties. Sokal and Sneath prepared a list of similarity indices in every one of which calculation of similarity at different sample distances was based on existing similarity between the two samples.

Jaccard's index is one of the oldest and most widely used indices that are used to evaluate similarities between various communities, and it is sometimes referred to as 
species overlap. This index, which is based on the presence or absence of individuals in two communities, can easily be calculated. Freestone and Inoouye studied similarities between plant species and soil properties in wetlands using Jaccard's index to analyze relationships between diversity and environmental heterogeneity. They concluded that environmental heterogeneity influenced dissimilarity between the studied communities, and that this dissimilarity had a significant and positive correlation with the distance between the studied communities, parent material, and soil texture. Barbercheck et al. stated that using Jaccard's index could somewhat reveal differences between virgin soils and disturbed soils in the three ecosystems of forest, wetlands and agricultural lands, but that its application required more accurate and detailed knowledge of all soil layers present in the mentioned ecosystems.

A geopedological framework can be used to broaden ecological studies beyond soil series by explicitly incorporating geologic and physiographic information. This approach can help researchers organize knowledge about intrinsic chemical and physical properties and extrinsic factors that influence vegetation patterns at multiple scales. This approach can be used in any region to supplement studies of vegetative-edaphic relationships based on maps of soil series [17].

How useful generalizability of soil data obtained from the study of sample area to areas outside of it can be, and whether it can reveal the actual situation that exists in the field, is something that must be tested in various studies in order to evaluate the applicability of the geopedological method. This research intended to study soil diversity by measuring it in a hierarchical sequence of soil taxonomy levels and through comparing similar units in the geopedological method, by using similarity and diversity indices, to investigate the degree of validity generalization the results of this method have for similar landforms in Miyaneh county in East Azerbaijani province, Iran.

\section{Materials and Methods}

\subsection{Selection of the Study Area}

The topography, geology, and geomorphology of East Azerbaijan Province, including Miyaneh, are such that landforms are frequently repeated. Therefore, a suitable place for the purposes of this research was found with an area of about 1500 ha, and average altitude of $1100 \mathrm{~m}, 5 \mathrm{~km}$ southeast of Miyaneh. Based on UTM, this area had longitude of 740,000.90 to 747,369.40 east, latitude of 4,138,113 to 4,143,403 m north (Figure 2), mean annual precipitation of $315.7 \mathrm{~mm}$, and average yearly temperature of $10.9^{\circ} \mathrm{C}$. Soil moisture and temperature regimes based on Franklin Newhall (NSM) method and its developed method ( $A$. vanvambeke) are dry xeric and mesic, respectively. The study area includes hill and, piedmont, valley, higher platueax landscapes, higher platueax form the main part of it, and it is located close to the Azarbaijan Steel proprietary road (the Miyaneh to Miandoab road).

\subsection{Landscape Analysis}

In the hierarchical structure of landscape analysis, six levels have been carefully consi- 
dered in the preparation of the soil map can be appropriate to the scale and level of accuracy desired, in accordance with the six-level, phenomena to be analyzed. Table 1 shows hierarchical structure and levels of perception of geoform units in landscape

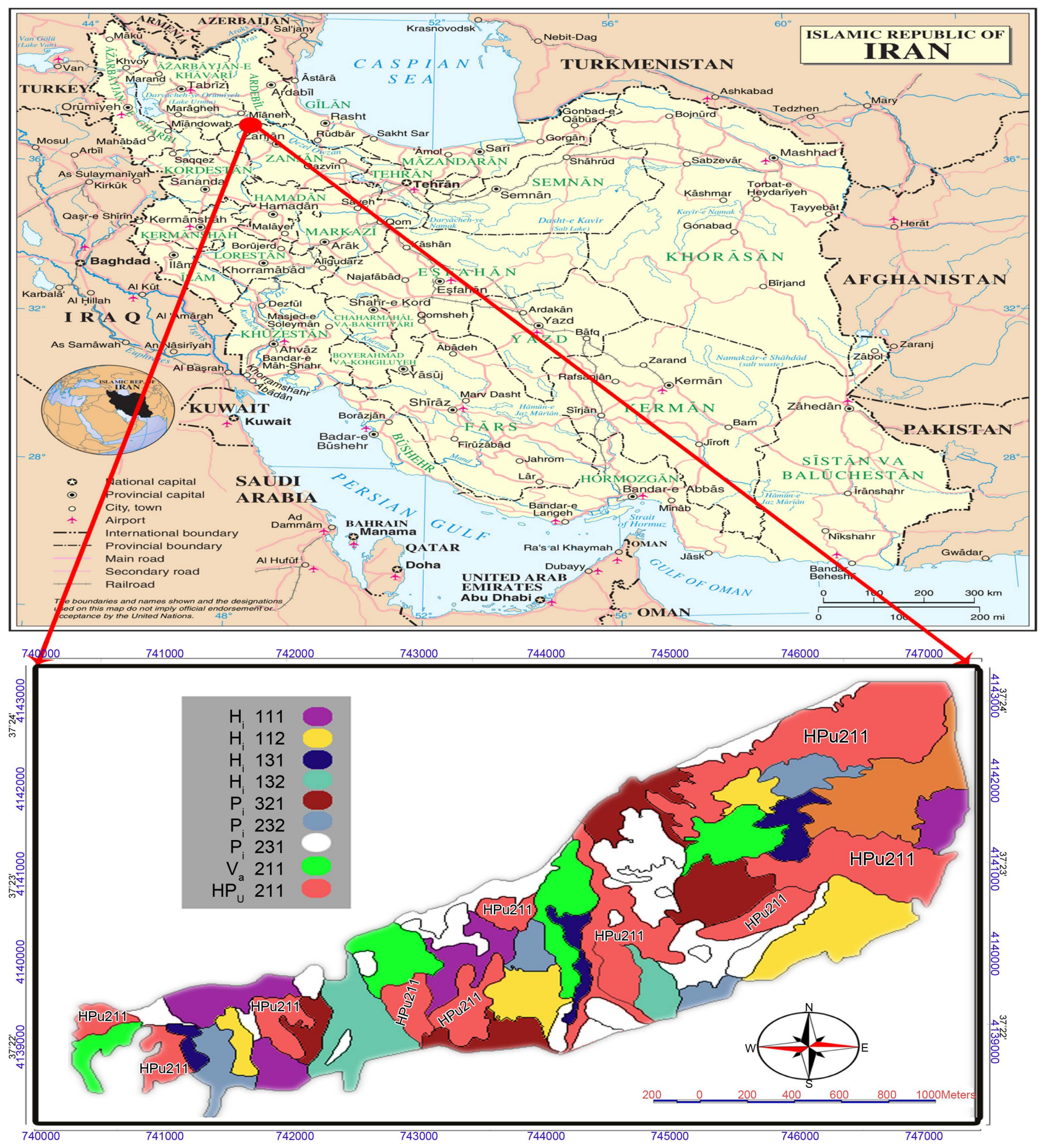

Figure 2. Location of the study area in the Miyaneh region, East Azerbaijan, Iran. 
Table 1. The overall look of landscape analysis.

\begin{tabular}{crc}
\hline Level & Classification & The concept of origin \\
\hline 6 & Geo structure & Order \\
5 & Morphogenetic environments & Suborder \\
4 & Landscape & Group \\
3 & Relief/molding & Subgroup \\
2 & Lithology/origin & Family \\
1 & Landform & Subfamily \\
\hline
\end{tabular}

analysis approach.

\subsection{Data Collection}

All the required equipment and tools were obtained to prepare the geopedological map of the area, including aerial photographs, topographic maps, and geologic maps at scales of 1:20,000, 1:20,000, and 1:100,000, respectively.

\subsection{Preparation of the Initial Interpretative Map (the Geoform Map) of the Study Area}

The aerial photographs at the scale of 1:20,000 were interpreted in stages based on the geomorphic viewpoint and considering the taxonomic classification system introduced by Zinck [2]. In this method, the soil-land relationship was used to distinguish units, and uniform lands were obtained based on geomorphological knowledge and considering geologic factors, topography and plant cover, and distribution and dispersion of landforms. Then, aerial photographs, taking into account factors such as background images, appearance of lands, slope, topography, land erosion and the natural drainage network and using a mirror stereoscope were interpreted, and then were scanned and entered into the ILWIS 3.4 software. In the later stages, Photos imported to the ILWIS 3.4 software using reference points picked up in the field, and also with the help of satellite images $\mathrm{ETM}^{+}$and ASTER from study area, were georeferenced. Finally, by digitizing the boundaries drawn on the individual photos, a primary interpretation map of study area was obtained. Finally, the boundary of the existing units in early commentary map during field operations reviewed and revised.

\subsection{Field Studies and Soil Sampling}

The geomorphological units in the study area were distinguished at different levels by interpretation of aerial photographs, through application of geopedological techniques at the scale of 1:20,000, and with the help of topographic and geologic maps. Soil survey studies were then conducted through selection of sample areas located within the area under study. Sample areas were selected in a way that at least one observational point in each map unit was excavated and studied. Sample areas were studied in detail. Outside of the sample areas, each distinguished unit on the soil map was examined in the field 
studies and if new units were found with soil series different from that determined in the sample areas, these units were dug and studied to determine the properties of the new soil series. After describing the profiles, the diagnostic horizons were sampled and the samples were sent to the laboratory for chemical and physical analyses.

During fieldwork, the borders between the units in the initial interpretative map were first controlled and corrected. Based on the stated principles for defining sample areas in the geopedological method, a part of the entire study area in the interpretative map was then selected (in a way that there was at least one example of each type of units in the initial interpretative map in the sample area) for taking soil samples.

The HPu211 unit, which exhibited good repeatability in the region and covered the largest part of the area under study, was considered a unit with a position different from those of the other units (Table 2). Based on grid sampling, and in the format of second order soil surveys [18], fifteen $2 \mathrm{~m}$ long, $1 \mathrm{~m}$ wide, and $1.5 \mathrm{~m}$ deep profiles were excavated $90 \mathrm{~m}$ apart from each other in the HPu211 unit. Nine other profiles were dug and studied in a similar unit located in an area that was called the generalization area located outside of the sample area.

Finally, all the excavated profiles were described based on the Field Book for Describing and Sampling Soils [19] and classified according to the USDA Keys to Soil Taxonomy [20]. Soil samples were taken from genetic horizons of all excavated profiles, the samples were air dried, and necessary laboratory analyses were performed on them. Finally, based on laboratory results, the soils were classified to the family and series levels.

\section{Similarity of the Soils}

Analyzing the frequent appearance of specific fundamental patterns found in landscapes is one of the methods used for discovering their dynamic and hidden structures, and use of similarity indices can be useful for this purpose. In this relation, Jaccard's similarity index ( $/$ ), in which common species between two communities and also the number of species in each one are considered, can be easily calculated. The following

Table 2. Units identified in the study area by geopedological approach, along with an area for each them.

\begin{tabular}{|c|c|c|c|c|}
\hline Landscape & Relief & Lithology & Landform & Area (ha) \\
\hline \multirow{5}{*}{$\mathrm{H}_{\mathrm{i}}$ Hilland } & \multirow{5}{*}{$\mathrm{H}_{\mathrm{i}} 1$ Low-lying hills } & $\mathrm{H}_{\mathrm{i}} 11$ Alternation of marl and & $\mathrm{H}_{\mathrm{i}} 111$ : A combination of shoulder and back slope & 60.50 \\
\hline & & metamorphosed marly limestone & $\mathrm{H}_{\mathrm{i}} 112$ : Foot slope & 58.65 \\
\hline & & & & \\
\hline & & $\mathrm{H}_{\mathrm{i}} 13$ Alluvial fans and Young alluvial & $\mathrm{H}_{\mathrm{i}} 131$ : A combination of shoulder and back slope & 10.75 \\
\hline & & terraces & $\mathrm{H}_{\mathrm{i}} 132$ : Foot slope & 12.25 \\
\hline \multirow{3}{*}{$\mathrm{P}_{\mathrm{i}}$ Piedmont } & $\mathrm{P}_{\mathrm{i}} 2$ Fan-shaped & $\mathrm{P}_{\mathrm{i}} 23$ Alluvial deposits of limestone and & $\mathrm{P}_{\mathrm{i}} 231$ : Active fan & 250.38 \\
\hline & $\begin{array}{c}\text { alluvium } \\
\mathrm{P}_{\mathrm{i}} 3 \text { Connections of }\end{array}$ & dolomite & $\mathrm{P}_{\mathrm{i}} 232$ : stream terraces covered by a Green meadow & 90.45 \\
\hline & fans & $\mathrm{P}_{\mathrm{i}} 32$ Dolomite and limestone & $\mathrm{P}_{\mathrm{i}} 321$ : Dense network of surface drainage & 260.95 \\
\hline$V_{a}$ Valley & Va2 River bed & Va21 River sediments & $V_{\mathrm{a}} 21$ : Set of stack and river terrace & 8.37 \\
\hline $\mathrm{HP}_{\mathrm{u}}$ Higher plateau & $\mathrm{HP}_{\mathrm{u}} 2 \mathrm{Mesa}$ & $\mathrm{HP}_{\mathrm{u}} 21$ Calcareous alluvial sediments & $\mathrm{HP}_{\mathrm{u}} 211:$ High and flat plateau & 480.65 \\
\hline
\end{tabular}


formula is used for this calculation:

$$
J=\frac{a}{(a+b+c)}
$$

The coefficients $a, b$, and $c$ represent the frequencies related to the states of presence and absence of the species. Table 3 explains how these coefficients are calculated.

In any case, the Jaccard index is only based on the presence or absence of the species, and their relative frequencies are not considered. Using the formula introduced by Manly is one of the available strategies for determining the similarity between two communities $(S)$ :

$$
S=1-\sum_{i=1}^{k}\left|p_{i}-q_{i}\right| / 2
$$

In the above relation, $p_{i}$ and $q_{i}$ represent the relative frequencies of the $I^{\text {th }}$ species in the first and second communities, respectively.

The numerical values of similarity indices mentioned above vary from zero to one. Zero indicates the species in the two communities are completely different, and one shows there is complete similarity between the species of the two communities.

In this research, the land unit $\mathrm{HPu} 211$, which had the highest delineation and good repeatability in the sample and generalization areas, and that covered the largest part of the study area (Table 3) was selected, and categories of soil taxonomy was compared in it for the different levels based on Jaccard's similarity and relative similarity indices. Moreover, the degree of validity generalization of the results obtained in the geopedological method was compared for the land unit mentioned above.

\section{Diversity of the Soils}

Various studies have investigated the importance of heterogeneity in landscape and of soil diversity identification [11], [13]-[15]. In this research, taxonomic pedodiversity at various levels (order, suborder, great group, subgroup, and family) and genetic pedodiversity at the level of horizons were studied for the sample and generalization areas. Soil diversity was analyzed through calculating richness index $(S)$, Shannon index $\left(H^{\prime}\right)$, and evenness index $(E)$ for the different levels of USDA soil taxonomy. The number of soil layers, or the components of every area, in the study and generalization areas were considered the richness index. Indices based on relative frequency of studied entities are the most common technique for measuring diversity. One of the most widely used

Table 3. Frequency of the presence and absence of species in two communities (Chao et al., 2005).

\begin{tabular}{ccc}
\hline & & The first community \\
The second community & Presence & Absence \\
Presence & a & b \\
Absence & c & -
\end{tabular}


diversity indices in ecology, which is used as a criterion for heterogeneity in the structure of a community, is the Shannon index [15]. The equation for this index is very similar to that Boltzmann introduced for determining entropy in thermodynamic systems, and that is why the Shannon index is also called the entropy index [11]. The mathematical expression for the Shannon index is as follows:

$$
H=-\sum_{i=1}^{n} p_{i} \cdot L n p_{i}
$$

In the above equation, $p_{i}$ represents the ratio of the components present in the $i^{\text {th }}$ unit. In fact, the actual value of $p_{i}$ is unknown and, hence, the $n_{i} / N$ ratio is used instead, where $n_{i}$ expresses the number of components belonging to the $i^{\text {th }}$ unit and $N$ is the total number of collected components.

The maximum possible entropy $\left(H_{\max }^{\prime}\right)$ happens for specific conditions of richness in a situation where all the components (various layers) have equal probability [11], [13]. In other words, mathematically speaking, this happens when the following condition is satisfied:

$$
H^{`}=H_{\text {max }}^{`}=\ln S
$$

Under such conditions, the ratio of observed diversity reaches the maximum possible value and is considered a criterion of evenness [11], [13], [15], and its mathematical expression is as follows:

$$
E=H^{\top} / H_{\max }^{`}=H^{\prime} / \ln S
$$

The evenness index can have any value from zero to one. One indicates a situation where all species or entities have equal probability (for example, when the different species occupy equal areas). Zero represents a situation where heterogeneity is observed in the relative frequency of the species; in other words, when one species is dominant over all others [11].

As stated by Saldana and Ibanez [15], there is no difference between soil diversity calculated from the surface that the samples represent and the diversity calculated from the number of the species. Therefore, in this study, the number of soil classes was used for calculating and assessing taxonomic pedodiversity indices, for determining the numbers and sequences of soil horizons at each category of soil taxonomy, and for calculating genetic pedodiversity.

Taylor pointed out that if the Shannon index was calculated for various communities (units), the calculated indices would follow normal distribution. This property allows the use of classic statistics for comparing diversity in various communities. Therefore, we used the following form of the $t$ distribution [21] to test statistically the reliability of distinguishing the repeatable unit (HPu211) in the study and generalization areas:

$$
T=\left(H_{1}^{\prime}-H_{2}^{\prime}\right) /\left(\operatorname{VarH}_{1}^{\prime}+\operatorname{VarH}_{2}^{\prime}\right)^{1 / 2}
$$

In the above equation, $H_{i}^{`}$ is the calculated diversity index for the $I^{\text {th }}$ unit, and $\operatorname{VarH}^{`}$ the calculated diversity variance for the $I^{\text {th }}$ unit (which is calculated as follows):

$$
\operatorname{VarH}_{i}=\left\{\left[\sum p_{i}\left(\ln p_{i}\right)^{2}-\left(\sum p_{i} \ln p_{i}\right)^{2}\right] / N\right\}+\left\{(S-1) / 2 N^{2}\right\}
$$


Under such conditions, the degree of freedom for reading the $t$ value in the table is obtained from the following formula:

$$
\text { d.f }=\left(\operatorname{VarH}_{i}^{\prime}+\operatorname{VarH}_{2}^{\prime}\right)^{2} /\left\{\left(\operatorname{VarH}_{1}^{\prime}\right)^{2} / N_{1}+\left[\left(\operatorname{VarH}_{2}^{\prime}\right)^{2} / N_{2}\right]\right\}
$$

In the above relation, $N_{i}$ is the number of samples taken from the $i^{\text {th }}$ unit. If the calculated $\mathrm{t}$ value is greater than the $t$ value in the table, the null hypothesis that the sample and the generalization areas have the same average number of repeatable units is HPu211 rejected.

\section{Results and Discussion}

\subsection{Indices of Jaccard Similarity and Relative}

The results of applying Jaccard index $\left(J=\frac{a}{(a+b+c)}\right)$ in order to measure the similarity between HPu211 unit in the sample and validation area, indicates that to the great group level these two regions are full of similarities but at the subgroups and family levels the similarity decreases to $60 \%$ and $25 \%$ respectively (Figure 3 ). The similarity between the soils of sample and validation areas considering the relative abundance of soil types available and using the Manley formula in both areas was calculated (Figure 4). Compare the relative similarity of these areas for different levels of soil taxonomy show that the categories of order and suborder have same relative similarity but in the next lower categories gradually decreased. Comparing the Figure 3 and Figure 4 show that considering the relative abundance of soil types in the HPu211 unit within the sample and validation areas, Jaccard similarity index of $100 \%$ to $90 \%$ for order and suborder levels, and $75 \%$ for great group level dropped. But at the categories of subgroup and family, the relative similarity index than Jaccard's index at each 5\% increased. Although in the soil family level Jaccard similarity has increased from $25 \%$ to $30 \%$. However, this similarity is still less than $50 \%$. In the other words, calculated similarity difference between the subgroup and family in both the method used (Jaccard

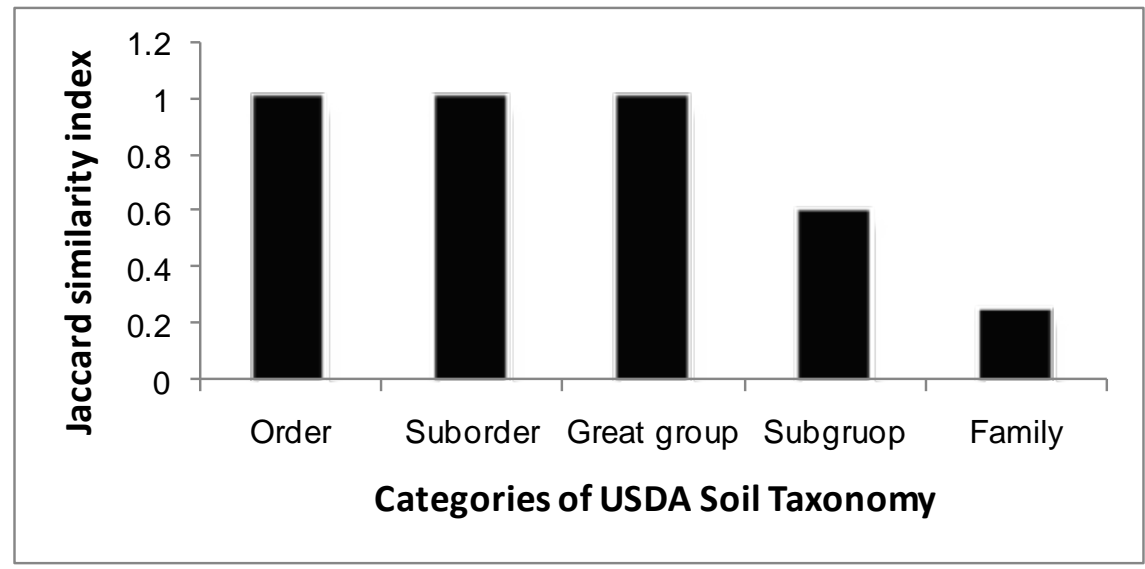

Figure 3. Comparison of Jaccard similarity index within the sample and validation areas in different categories of USDA soil taxonomy. 


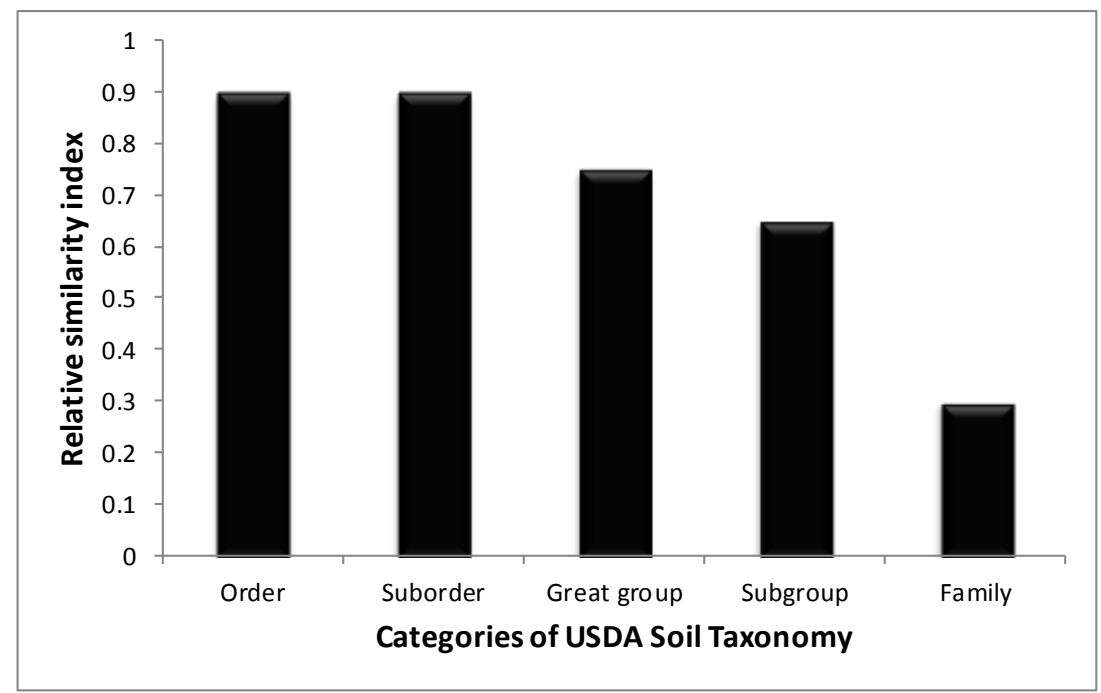

Figure 4. Comparison of relative similarity index within the sample and validation areas in different categories of USDA soil taxonomy.

index and the relative similarity), gross and significant. Since the most appropriate scale of study for geopedological approach semi-detailed $(1: 50,000$ to $1: 100,000)$ to brief $(1: 100,000$ to $1: 250,000)$ is expressed [1], [22] and it is believed that in order to study at larger scales, used strategy is the need to change and edit [1]. Doing this research in a detailed scale $(1: 10,000$ to $1: 25,000)$, according to the researchers is confirmed and states that the internal variability of the similar map units is not consistent. As a result, according to this method, taxonomy results obtained from the sample area, are not generalizable to similar landforms on a scale of 1:20,000. In the other words, in the most optimistic case, it may be said that geopedological approach for higher levels of subgroups, can be used in order to generalize the results to similar geomorphic units with large-scales and to lower categories of UASA soil taxonomy i.e. subgroup, family and series does not have the necessary efficiency. However, one possible way to edit the approach used in geopedology in detailed and larger scales, is the definition of "landform phases". This means that you get more information with finer details from recent scales can be do better separated from the landscapes under uniform units (homogeneous). Landform phases can be determined by observation of field evidence such as the percentage of surface stone and gravel, the type and amount of vegetation, as well as using the information received from the DEM and its derivatives (like aspect map and slop map) or according to hydrological conditions in the study area determined.

\subsection{Indices of Pedodiversity, Richness and Evenness}

Table 4 shows the calculated diversity indices in the USDA soil taxonomy hierarchy for the HPu211 unit present in the sample and generalization areas. Comparison of Shannon's diversity index for the various USDA soil taxonomy levels in the two mentioned areas is shown in Figure 5. Based on obtained results, the value of Shannon's diversity index increased from the order to the family levels in both areas because of the simul- 
taneous rise in richness and evenness that occurred in downscaling use of small scale information for analysis of large scale studies [14].

Ibanez et al. [13] and Saldana and Ibanez [15] also showed how values of Shannon and richness indices increased in soil taxonomy hierarchy in small- and large-scale studies. The interesting point in Figure 5 is that, despite the small number of soil profiles in the generalization area (14 profiles), the calculated diversity in taxonomy is higher compared to the sample area ( 28 profiles) due to the greater evenness, while at the subgroup and family levels of the soils, the sample area exhibits greater diversity. In fact, as Phillips also stated calculated entropies were a representative of the intertwined and complex nature of various types of the soil present at the various USDA taxonomy levels, and that this complex nature resulted from the combination of random and non-random processes in the environment [14].

Statistical comparison of taxonomic diversity of Shannon between the two similar

Table 4. Pedodiversity analysis for HPu211 unit within sample and validation areas in different categories of USDA soil taxonomy.

\begin{tabular}{ccccccc}
\hline Category & Location & $N$ & $S$ & $H^{\prime}$ & $H^{\prime}{ }^{\prime}{ }^{\prime}$ & $E$ \\
\hline \multirow{2}{*}{ Order } & Sample area Validation area & 15 & 2 & 0.58 & 0.69 & 0.83 \\
& & 9 & 2 & 0.67 & 0.69 & 0.97 \\
Suborder & Sample area Validation area & 15 & 2 & 0.58 & 0.69 & 0.83 \\
& & 9 & 2 & 0.67 & 0.69 & 0.97 \\
Great group & Sample area Validation area & 15 & 3 & 0.75 & 1.10 & 0.69 \\
& & 9 & 3 & 0.85 & 1.10 & 0.78 \\
Subgroup & Sample area Validation area & 15 & 4 & 1.23 & 1.39 & 0.89 \\
& & 9 & 4 & 1.17 & 1.39 & 0.84 \\
Family & Sample area Validation area & 15 & 12 & 2.33 & 2.48 & 0.94 \\
& & 9 & 17 & 1.71 & 1.95 & 0.88 \\
\hline
\end{tabular}

$N$ : Total samples, $S:$ Richness (number of taxons in any category), $H^{\prime}:$ Shannon's pedodiversity, $H_{\text {max }}^{\prime}$ : maximum diversity, $E$ : Evenness.

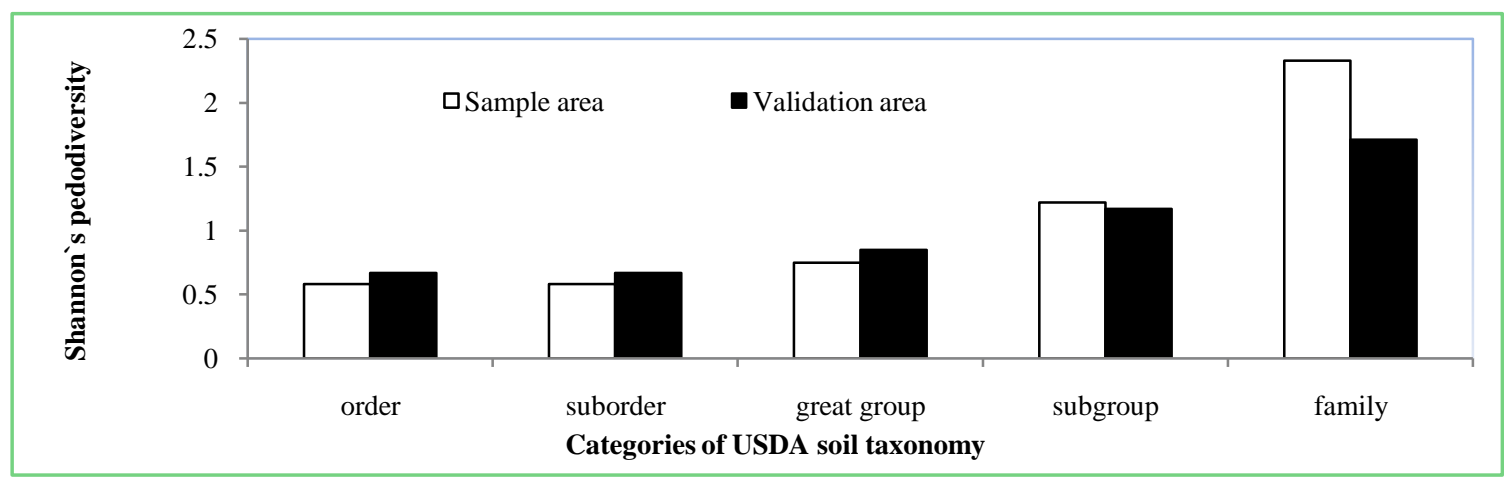

Figure 5. Comparison of $\mathrm{HPu} 211$ within the sample and validation areas using Shannon index in different categories of USDA soil taxonomy. 
HPu211 units in the sample and generalization areas revealed that there were significant differences between the means of soil diversity at the confidence level of $95 \%$ for the family level (Table 5). In other words, up to the subgroup level, the soils in the two mentioned areas were statistically identical. However, at the family level the difference between the soils in the two similar HPu211 units in the sample and generalization areas became apparent due to changes in the value of the richness index. Therefore, such differences will be more pronounced at levels lower than family (series and phases of soil series).

Even by changing the understanding level and concentrating on the sequence of genetic horizons in the dug profiles in the sample and generalization areas, increased soil diversity in the USDA soil hierarchical taxonomy was proved. Tables 6-9 show Shannon's genetic diversity for the various levels of taxonomy present in the two mentioned areas. These results conform to those Ibanez et al. [11] found in their study of diversity of soil map units in Spain, and also agree with information obtained from studies on soil diversity in the Zayandeh-Rood Valley in Esfahan conducted by Toomanian et al. [14].

Table 5. Statistical comparison of pedodiversity between HPu211 unit in sample and validation areas in different categories of USDA soil taxonomy.

\begin{tabular}{|c|c|c|c|c|c|c|}
\hline \multirow{2}{*}{ Category } & \multicolumn{2}{|c|}{ Shannon's diversity } & \multicolumn{2}{|c|}{ Variance of Shannon's diversity } & \multirow{2}{*}{$d f$} & \multirow{2}{*}{$t$} \\
\hline & Sample area & Validation area & Sample area & Validation area & & \\
\hline Order & 0.576 & 0.673 & 0.012 & 0.005 & 31 & 0.74 \\
\hline Suborder & 0.576 & 0.673 & 0.012 & 0.005 & 31 & 0.74 \\
\hline Great group & 0.753 & 0.853 & 0.033 & 0.026 & 34 & 0.412 \\
\hline Subgroup & 1.234 & 1.171 & 0.019 & 0.029 & 31 & 0.286 \\
\hline Family & 2.333 & 1.709 & 0.032 & 0.043 & 32 & $\star 2.276$ \\
\hline
\end{tabular}

*: Significant at $5 \%$ level of probability.

Table 6. Comparison of Shannon's genetic diversity in sample and validation areas in HPu211 unit for different soil orders/suborders.

\begin{tabular}{|c|c|c|c|c|c|c|c|}
\hline Location & Order/Suborder & Profile type & $n_{i}$ & $H^{\prime}$ & $S$ & $H_{\max }^{\prime}$ & $E$ \\
\hline \multirow{4}{*}{ 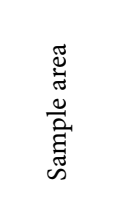 } & \multirow{2}{*}{ Entisols/Orthents } & $\mathrm{A}_{\mathrm{p}} / \mathrm{C}_{1} / \mathrm{C}_{2}$ & 4 & \multirow{2}{*}{0.67} & \multirow{2}{*}{2} & \multirow{2}{*}{0.69} & \multirow{2}{*}{0.97} \\
\hline & & $\mathrm{A}_{\mathrm{p}} / \mathrm{C}_{1} / \mathrm{C}_{2} / \mathrm{C}_{3}$ & 3 & & & & \\
\hline & Jno & $\mathrm{A}_{\mathrm{p}} / \mathrm{B}_{\mathrm{w} 1} / \mathrm{B}_{\mathrm{w} 2} / \mathrm{B}_{\mathrm{w} 3} / \mathrm{C}$ & 5 & \multirow{2}{*}{0.54} & \multirow{2}{*}{2} & \multirow{2}{*}{0.69} & \multirow{2}{*}{0.78} \\
\hline & 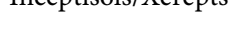 & $\mathrm{A}_{\mathrm{p}} / \mathrm{B}_{\mathrm{w} 1} / \mathrm{B}_{\mathrm{w} 2} / \mathrm{B}_{\mathrm{w} 3}$ & 3 & & & & \\
\hline \multirow{4}{*}{ 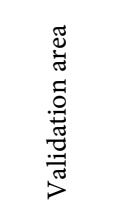 } & Entisols/Orthents & $\mathrm{A}_{\mathrm{p}} / \mathrm{C}_{1} / \mathrm{C}_{2}$ & 3 & 0 & 1 & 0 & 0 \\
\hline & \multirow{3}{*}{ Inceptisols/Xerepts } & $\mathrm{A}_{\mathrm{p}} / \mathrm{B}_{\mathrm{k} 1} / \mathrm{B}_{\mathrm{k} 2} / \mathrm{B}_{\mathrm{k} 3}$ & 2 & \multirow{3}{*}{1.04} & \multirow{3}{*}{3} & \multirow{3}{*}{1.1} & \multirow{3}{*}{0.95} \\
\hline & & $\mathrm{A}_{\mathrm{p}} / \mathrm{B}_{\mathrm{k} 1} / \mathrm{B}_{\mathrm{k} 2} / \mathrm{C} / \mathrm{B}_{\mathrm{yb}}$ & 2 & & & & \\
\hline & & $\mathrm{A}_{\mathrm{p}} / \mathrm{B}_{\mathrm{wss}} / \mathrm{B}_{\mathrm{k}} / \mathrm{C}$ & 2 & & & & \\
\hline
\end{tabular}

$n_{i}$ : Numbers of horizon's sequence frequency, $S$ : Richness, $H^{\prime}$ : Shannon's pedodiversity, $H_{\text {max }}^{\prime}$ maximum diversity, E: Evenness. 
Table 7. Comparison of Shannon's genetic diversity in sample and validation areas in HPu211 unit for different soil great groups.

\begin{tabular}{|c|c|c|c|c|c|c|c|}
\hline Location & Soil great group & Profile type & $n_{i}$ & $H^{\prime}$ & $S$ & $H_{\max }^{\prime}$ & $E$ \\
\hline \multirow{3}{*}{ 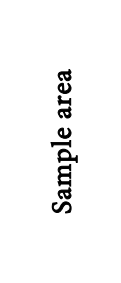 } & Xerorthents & $\begin{array}{c}\mathrm{A}_{\mathrm{p}} / \mathrm{C}_{1} / \mathrm{C}_{2} / \mathrm{C}_{3} \\
\mathrm{~A}_{\mathrm{p}} / \mathrm{C}_{1} / \mathrm{C}_{2}\end{array}$ & $\begin{array}{l}4 \\
3\end{array}$ & 0.68 & 2 & 0.69 & 0.98 \\
\hline & Calcixerepts & $\begin{array}{c}\mathrm{A}_{\mathrm{p}} / \mathrm{B}_{\mathrm{k} 1} / \mathrm{B}_{\mathrm{k} 2} / \mathrm{B}_{\mathrm{k} 3} \\
\mathrm{~A}_{\mathrm{p}} / \mathrm{B}_{\mathrm{wss}} / \mathrm{B}_{\mathrm{k}} / \mathrm{C}\end{array}$ & $\begin{array}{l}3 \\
1\end{array}$ & 0.56 & 2 & 0.69 & 0.82 \\
\hline & Haploxerepts & $\mathrm{A}_{\mathrm{p}} / \mathrm{B}_{\mathrm{w} 1} / \mathrm{B}_{\mathrm{w} 2} / \mathrm{B}_{\mathrm{w} 3}$ & 4 & 0 & 1 & 0 & 0 \\
\hline \multirow{3}{*}{ 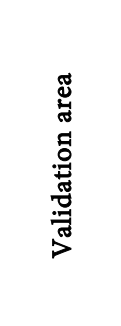 } & Xerorthents & $\begin{array}{c}\mathrm{A}_{\mathrm{p}} / \mathrm{C}_{1} / \mathrm{C}_{2} \\
\mathrm{~A}_{\mathrm{p}} / \mathrm{C}_{1} / \mathrm{C}_{2} / \mathrm{C}_{3}\end{array}$ & $\begin{array}{l}2 \\
1\end{array}$ & 0.64 & 2 & 0.69 & 0.92 \\
\hline & Calcixerepts & $\begin{array}{c}\mathrm{A}_{\mathrm{p}} / \mathrm{B}_{\mathrm{k} 1} / \mathrm{B}_{\mathrm{k} 2} / \mathrm{B}_{\mathrm{k} 3} \\
\mathrm{~A}_{\mathrm{p}} / \mathrm{B}_{\mathrm{wss}} / \mathrm{B}_{\mathrm{k}} / \mathrm{C}\end{array}$ & $\begin{array}{l}2 \\
2\end{array}$ & 0.69 & 2 & 0.69 & 1 \\
\hline & Haploxerepts & $\begin{array}{c}\mathrm{A}_{\mathrm{p}} / \mathrm{B}_{\mathrm{w} 1} / \mathrm{B}_{\mathrm{w} 2} / \mathrm{C} \\
\mathrm{A}_{\mathrm{p}} / \mathrm{B}_{\mathrm{w} 1} / \mathrm{B}_{\mathrm{w} 2} / \mathrm{B}_{\mathrm{w} 3}\end{array}$ & $\begin{array}{l}1 \\
1\end{array}$ & 0.69 & 2 & 0.69 & 1 \\
\hline
\end{tabular}

$n_{i}$ : Numbers of horizon's sequence frequency, $S$ : Richness, $H$ : Shannon's pedodiversity, $H_{\text {max }}^{\text {' }}$ maximum diversity, E: Evenness.

Table 8. Comparison of Shannon's genetic diversity in sample and validation areas in HPu211 unit for different soil subgroups.

\begin{tabular}{|c|c|c|c|c|c|c|c|}
\hline Location & Soil subgroup & Profile type & $\boldsymbol{n}_{\boldsymbol{i}}$ & $H^{\prime}$ & $S$ & $H_{\text {max }}^{\prime}$ & $E$ \\
\hline \multirow{6}{*}{ 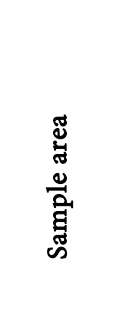 } & \multirow[b]{2}{*}{ Typic Xerorthents } & $\mathrm{A}_{\mathrm{p}} / \mathrm{C}_{1} / \mathrm{C}_{2} / \mathrm{C}_{3}$ & 4 & \multirow[b]{2}{*}{0.64} & \multirow[b]{2}{*}{2} & \multirow[b]{2}{*}{0.69} & \multirow[b]{2}{*}{0.92} \\
\hline & & $\mathrm{A}_{\mathrm{p}} / \mathrm{C}_{1} / \mathrm{C}_{2}$ & 2 & & & & \\
\hline & Tynic Colcixerents & $\mathrm{A}_{\mathrm{p}} / \mathrm{B}_{\mathrm{k} 1} / \mathrm{B}_{\mathrm{k} 2} / \mathrm{B}_{\mathrm{k} 3} / \mathrm{B}_{\mathrm{k} 4}$ & 3 & \multirow{2}{*}{0.68} & \multirow{2}{*}{2} & \multirow{2}{*}{0.69} & \multirow{2}{*}{0.98} \\
\hline & 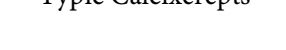 & $\mathrm{A}_{\mathrm{p}} / \mathrm{B}_{\mathrm{k} 1} / \mathrm{B}_{\mathrm{k} 2} / \mathrm{B}_{\mathrm{k} 3} / \mathrm{B}_{\mathrm{km}}$ & 2 & & & & \\
\hline & \multirow{2}{*}{ Fluventic Haploxerepts } & $\mathrm{A}_{\mathrm{p}} / \mathrm{B}_{\mathrm{w} 1} / \mathrm{B}_{\mathrm{w} 2} / \mathrm{B}_{\mathrm{w} 3}$ & 1 & \multirow{2}{*}{0.69} & \multirow{2}{*}{2} & \multirow{2}{*}{0.69} & \multirow{2}{*}{1} \\
\hline & & $\mathrm{A}_{\mathrm{p}} / \mathrm{B}_{\mathrm{w} 1} / \mathrm{B}_{\mathrm{w} 2} / \mathrm{C}$ & 1 & & & & \\
\hline \multirow{9}{*}{ 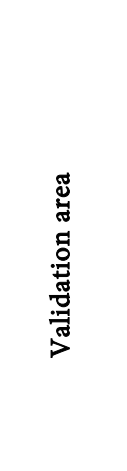 } & Gypsic Haploxerepts & $\mathrm{A}_{\mathrm{p}} / \mathrm{B}_{\mathrm{y} 1} / \mathrm{B}_{\mathrm{y} 2} / \mathrm{C}$ & 2 & 0 & 1 & 0 & 0 \\
\hline & \multirow{2}{*}{ Typic Xerorthents } & $\mathrm{A}_{\mathrm{p}} / \mathrm{C}_{1} / \mathrm{C}_{2}$ & 2 & \multirow{2}{*}{0.64} & \multirow{2}{*}{2} & \multirow{2}{*}{0.69} & \multirow{2}{*}{0.92} \\
\hline & & $\mathrm{A}_{\mathrm{p}} / \mathrm{C}_{1} / \mathrm{C}_{2} / \mathrm{C}_{3}$ & 1 & & & & \\
\hline & \multirow{3}{*}{ Typic Calcixerepts } & $\mathrm{A}_{\mathrm{p}} / \mathrm{B}_{\mathrm{k} 1} / \mathrm{B}_{\mathrm{k} 2} / \mathrm{B}_{\mathrm{k} 3}$ & 1 & \multirow{3}{*}{1.10} & \multirow{3}{*}{3} & \multirow{3}{*}{1.10} & \multirow{3}{*}{1} \\
\hline & & $\mathrm{A}_{\mathrm{p}} / \mathrm{B}_{\mathrm{k} 2} / \mathrm{B}_{\mathrm{k}} / \mathrm{C}$ & 1 & & & & \\
\hline & & $\mathrm{A}_{\mathrm{p}} / \mathrm{B}_{\mathrm{k}} / \mathrm{B}_{\mathrm{km}}$ & 1 & & & & \\
\hline & \multirow{2}{*}{ Fluventic Haploxerepts } & $\mathrm{A}_{\mathrm{p}} / \mathrm{B}_{\mathrm{w} 1} / \mathrm{B}_{\mathrm{w} 2} / \mathrm{C}$ & 1 & \multirow{2}{*}{0.69} & \multirow{2}{*}{2} & \multirow{2}{*}{0.69} & \multirow{2}{*}{1} \\
\hline & & $\mathrm{A}_{\mathrm{p}} / \mathrm{B}_{\mathrm{w} 1} / \mathrm{B}_{\mathrm{w} 2} / \mathrm{B}_{\mathrm{w} 3}$ & 1 & & & & \\
\hline & Vertic Haploxerepts & $\mathrm{A}_{\mathrm{p}} / \mathrm{B}_{\mathrm{wss}} / \mathrm{B}_{\mathrm{k}} / \mathrm{C}$ & 1 & 0 & 1 & 0 & 0 \\
\hline
\end{tabular}

$n_{i}$ : Numbers of horizon's sequence frequency, $S$ : Richness, $H$ : Shannon's pedodiversity, $H_{\text {max }}^{\prime}$ maximum diversity, E: Evenness.

Figure 6(a) compares Shannon's genetic diversity for the HPu211 units present in the sample and validation areas at the levels of order/suborder. At these levels, the diversity in the Entisols of the sample area is greater compared to the Inceptisols, while 
Table 9. Comparison of Shannon's genetic diversity in sample and validation areas in HPu211 unit for different soil family.

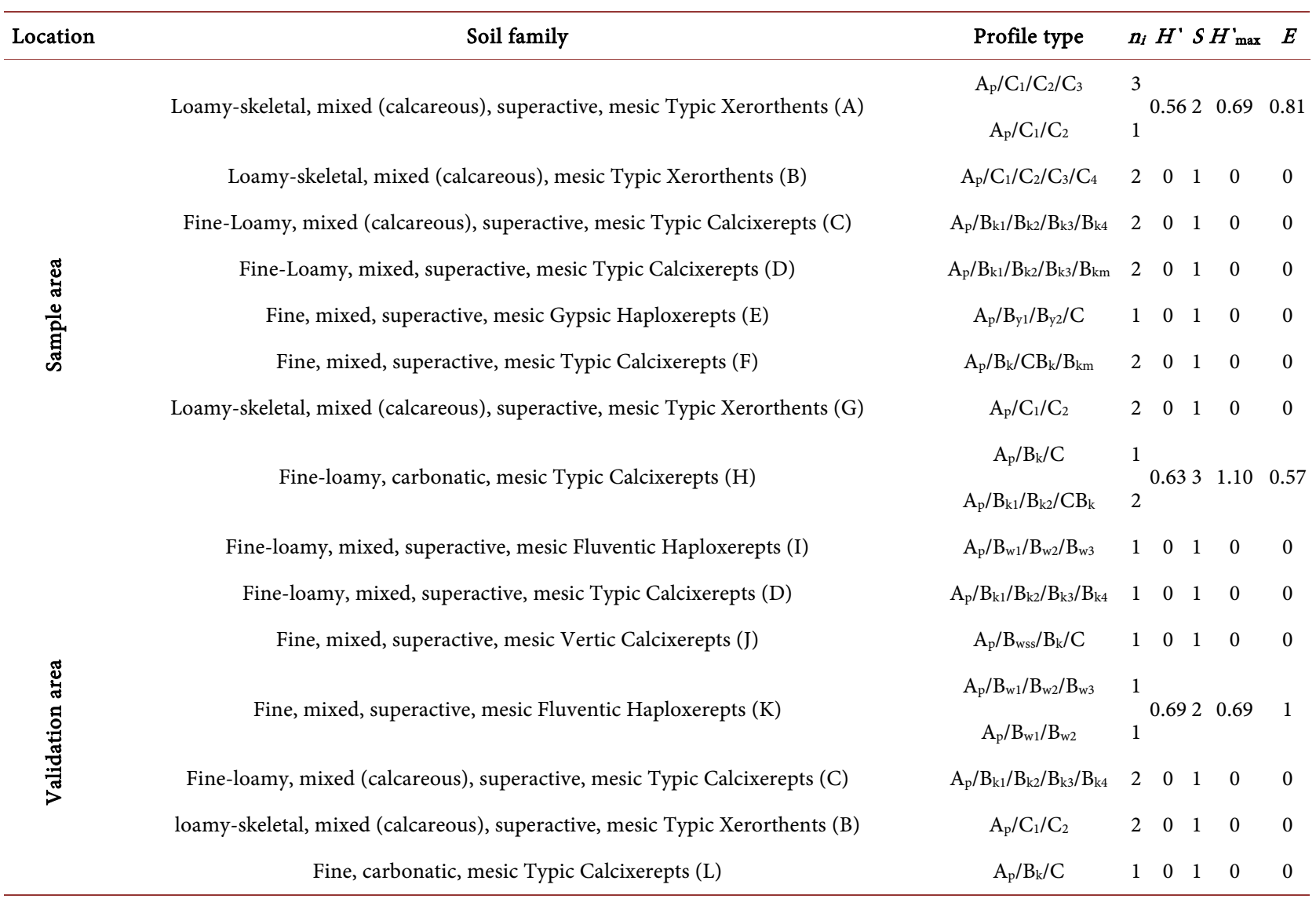

$n_{i}$ : Numbers of horizon's sequence frequency, $S$ : Richness, $H$ : Shannon's pedodiversity, $H$ 'max: maximum diversity, $E$ : Evenness *: To ease charting the genetic diversity, every family with a Latin letter is displayed.

the reverse situation exists in the generalization area: the Inceptisols enjoy greater diversity.

Shannon's genetic diversity for the HPu211 units in the sample and generalization areas is compared at the level of soil great groups in Figure 6(b). At this level, the soil great group of Xerorthents has the maximum and the Haploxereps soil great group the minimum degree of diversity in the sample area. However, in the generalization area, the Haploxereps, together with the soil great groups Calcixerepts and Xerorthents, possess identical and high genetic diversities.

Figure 6(c) compares Shannon's genetic diversity for the HPu211 units in the sample and generalization areas at the level of subgroup. At this level, the subgroups Fluventic Haploxerepts and Gypsic Haploxereps have the highest and lowest degree of genetic diversity in the sample area, respectively. However, the Typic Calcixerepts subgroup possesses the greatest degree of genetic diversity in the generalization area and the three subgroups Fluventic Haploxerepts, Typic Xerorthents, and Vertic Haploxerepts (in that order) have the lowest genetic diversity.

At the level of family, six soils (A, E, F, G, H, I) were studied and identified in the sample area, but they were not found in the generalization area. Moreover, three new soil 


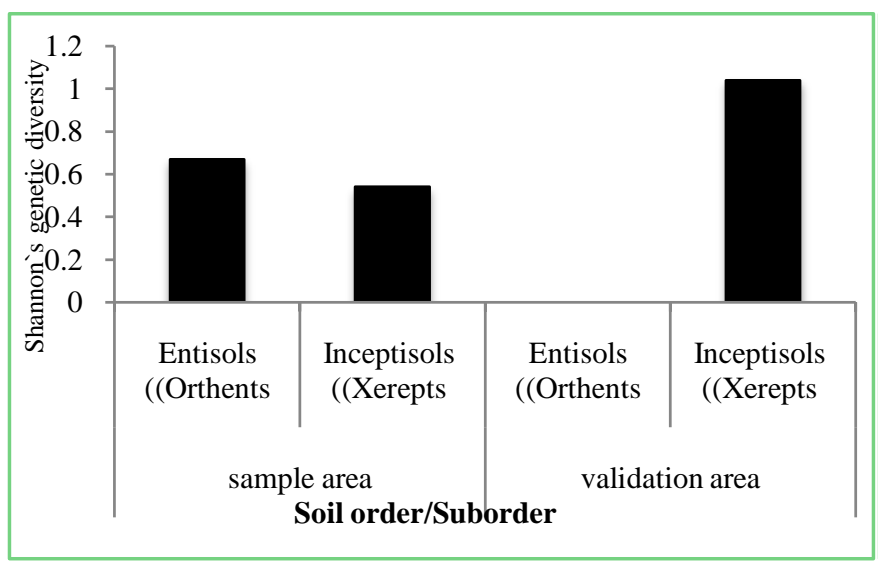

(a)

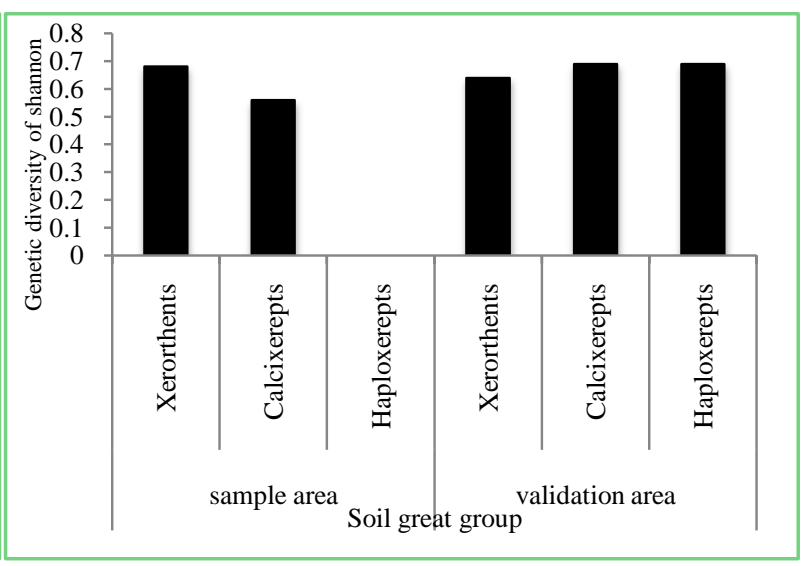

(b)

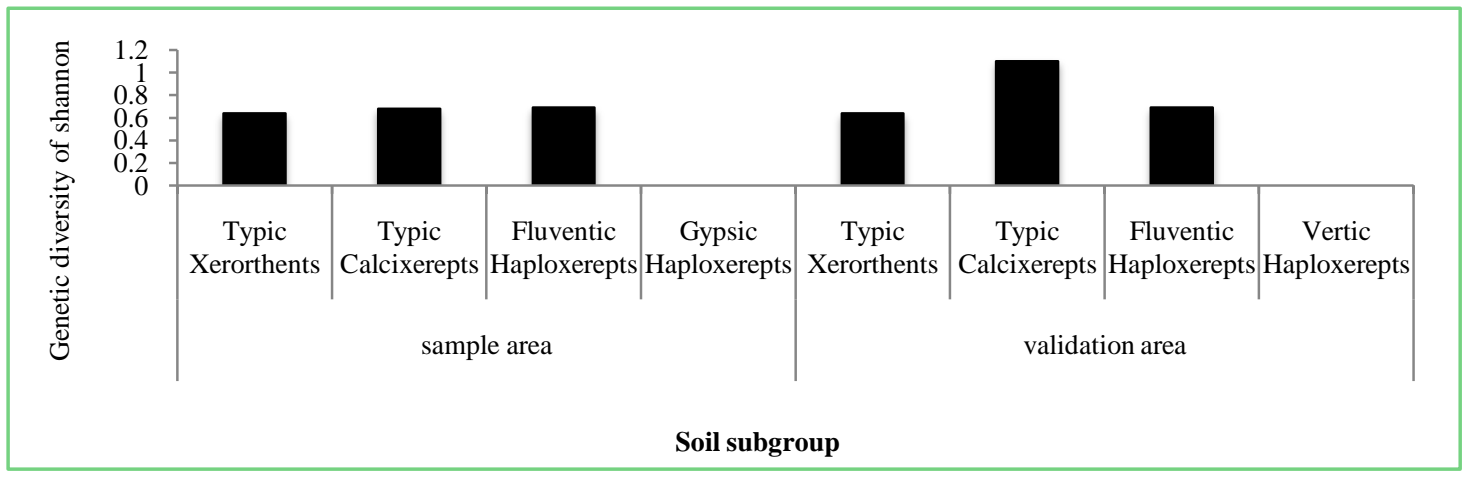

(c)

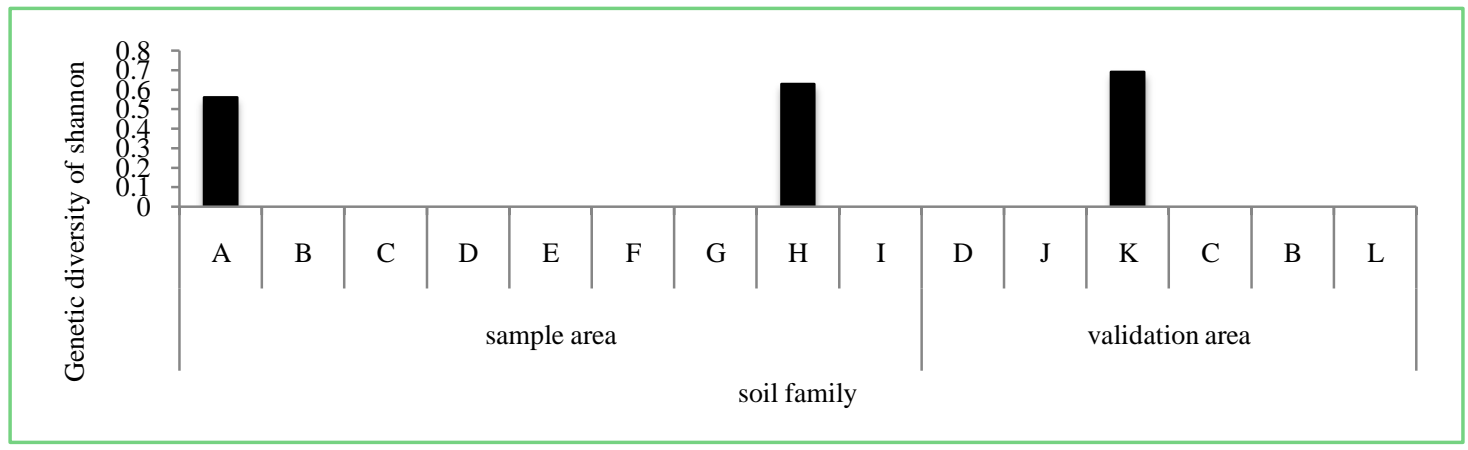

(d)

Figure 6. Comparison of Shannon's genetic diversity in sample and validation areas for different categories of USDA soil taxonomyç order or suborder (a), great group (b), subgroup (c) and family (d).

families $(\mathrm{J}, \mathrm{K}$, and $\mathrm{L})$ were found in the generalization area that had not been observed in the sample area before. These three soil families belong to the Inceptisols and, interestingly, the $\mathrm{K}$ family enjoys the greatest genetic diversity in the two areas. The $\mathrm{H}$ family also has the greatest degree of diversity in the sample area (Figure 6(d)).

Therefore, despite the similarity of the studied geomorphic units in the sample and generalization areas, investigation of genetic diversity in the USDA soil taxonomy hierarchy presented in Figure 6 reveals differences in relation to the received information concerning soil types and their changeability. The soils in the sample and generalization 
areas are identical only up to the soil great group. However, in relation to their genetic diversity, there are similarities between these two areas even at the highest levels (order and suborder).

\section{General Conclusion}

Results indicated that classification of the profiles dug in the generalization area was different from that of the profiles dug in the sample area at the soil family level. Moreover, the position of the sample area had a considerable effect on soil txonomy, the type of map unit, and on the degree of generalizability of similar units. Therefore, taxonomic generalizability of geopedological results for similar landforms cannot yield a good pattern in relation to management of the region. However, since there are minor differences in properties such as percentage gravel, presence or absence of clay cover, clay content, and calcium carbonate percentage (that are important from the viewpoint of soil taxonomy, and can sometimes also cause substantial changes even at the level of order), these soils are considered similar with respect to management and usage. Therefore, it is possible that management generalizability in this method, even at the detailed scale, can satisfy the related needs. Consequently, interpretative or managerial purity of geopedological units must be considered in future research.

\section{References}

[1] Rossiter, D.G. (2000) Lecture Notes and Reference Methodology for Soil Resource Inventories. Second Revised Version, Institute for Aerospace Survey and Earth Sciences (International Institute for Geo-Information Science and Earth Observation), Enschede.

[2] Zinck, J.A. (1989) Physiography and Soils, Lecture Notes for Soil Students. Soil Science Division, Soil Survey Courses Subject Matter, Enschede, The Netherlands.

[3] Rossiter, D.G., Girma, A., Henneman, R. and Siderus, W. (2001) Summary of Investigation, 1997-2000 by ITC. Technical Report, International Institute for Geo-Information Science and Earth Observation, Soil Science Division, The Netherlands, 31 p.

[4] Saldana, A. (2016) Geopedology, A Tool for Soil-Geoform Pattern Analysis. Springer, Berlin, 239-250. http://dx.doi.org/10.1007/978-3-319-19159-1_14

[5] Dent, D. and Young, A. (1981) Soil Survey and Land Evaluation. Georg Allen and Unwin Publishers, London.

[6] Western, S. (1978) Soil Survey Contracts and Quality Control. Clarendon Press, Oxford, England.

[7] Zhu, J.X., Hudson, B., Burt, J., Lubich, K. and Simonson, D. (2001) Soil Mapping Using GIS, Expert Knowledge and Fuzzy Logic. Soil Science Society of American Journal, 65, 1463-1472. http://dx.doi.org/10.2136/sssaj2001.6551463x

[8] Esfandiarpoor Borujeni, I., Toomanian, N., Salehi, M.H. and Mohammadi, J. (2009) Assessing Geopedological Soil Mapping Using Diversity and Similarity Indices (A Case Study: Borujen Area, Chaharmahal-Va-Bakhtiari Province). Journal of Water and Soil, 23, 100114. [In Persian with English Abstract]

[9] Sharma, V.A.K. (2006) Mapping of the Soil. Science Publishers, New Hampshire.

[10] Guo, Y., Gong, P. and Amundson, R. (2003) Pedodiversity in the United States of America. Geoderma, 117, 99-115. http://dx.doi.org/10.1016/S0016-7061(03)00137-X 
[11] Ibanez, J.J., De Alba, S. and Bermudes, F.F. and Garsia-Alvarez, A. (1995) Pedodiversity: Concepts and Measurements. Catena, 24, 215-232. http://dx.doi.org/10.1016/0341-8162(95)00028-Q

[12] McBratney, A.B. and Minasny, B. (2007) On Measuring Pedodiversity. Geoderma, 141, 149-154. http://dx.doi.org/10.1016/j.geoderma.2007.05.012

[13] Ibanez, J.J., De Alba, S., lobo, A. and Zucarello, V. (1998) Pedodiversity and Global Soil Patterns at Coarse Scales (with Discussion). Geoderma, 83, 171-214. http://dx.doi.org/10.1016/S0016-7061(97)00147-X

[14] Toomanian, N., Jalalian, A., Khademi, H., Eghbal, M.K. and Papritz, A. (2006) Pedodiversity and Pedogenesis in Zayandeh-Rud Valley, Central Iran. Geomorphology, 81, 376-393. http://dx.doi.org/10.1016/j.geomorph.2006.04.016

[15] Saldana, A. and Ibanez, J.J. (2004) Pedodiversity Analysis at Large Scales: An Example of There Fluvial Terrain of the Henares River (Central Spain). Geoderma, 62, 123-138.

[16] Wolda, H. (1981) Similarity Indices, Sample Size and Diversity. Oecologia, 50, 296-302. http://dx.doi.org/10.1007/BF00344966

[17] Michaud, G.A., Monger, H.C. and Anderson, D.L. (2013) Geomorphic-Vegetation Relationships Using a Geopedological Classification System, Northern Chihuahuan Desert, USA. Journal of Arid Environments, 90, 45-54. http://dx.doi.org/10.1016/j.jaridenv.2012.10.001

[18] Anonymous (1993) Soil Survey Manual, Soil Survey Staff. Handbook 18, Government printing Office Publishers, Washington DC.

[19] Schoenberger, P.J., Wysocki, D.A., Benham, E.C. and Broderson, W.D. (2012) Field Book for Describing and Sampling Soils. 3rd Edition, Natural Resources Conservation Service, National Soil Survey Center, Lincoln, Nebraska.

[20] Anonymous (2014) Keys to Soil Taxonomy. 12th Edition, Soil Survey Staff, Natural Resources Conservation Service, National Soil Survey Center, United States Department of Agriculture, Lincoln, Nebraska.

[21] Hutcheson, K. (1970) A Test for Comparing Diversities Based on the Shannon Formula. Journal of Theoretical Biology, 29, 151-154. http://dx.doi.org/10.1016/0022-5193(70)90124-4

[22] Udomsri, S. (2006) Application of Computer Assisted Geopedology to Predictive Soil Mapping and Its Use in Assessing Soil Erosion Prone Areas: A Case Study of Doi Ang Khang, Ang Khang Royal Agricultural Station, Thailand. Master Thesis, International Institute for Geo-Information Science and Earth Observation (ITC), Enschede, The Netherlands. 
Submit or recommend next manuscript to SCIRP and we will provide best service for you:

Accepting pre-submission inquiries through Email, Facebook, LinkedIn, Twitter, etc.

A wide selection of journals (inclusive of 9 subjects, more than 200 journals)

Providing 24-hour high-quality service

User-friendly online submission system

Fair and swift peer-review system

Efficient typesetting and proofreading procedure

Display of the result of downloads and visits, as well as the number of cited articles

Maximum dissemination of your research work

Submit your manuscript at: http://papersubmission.scirp.org/

Or contact ojg@scirp.org 